\title{
DEVELOPMENT OF LIFE AND CAREER SKILLS SCALE FOR UNIVERSITY STUDENTS
}
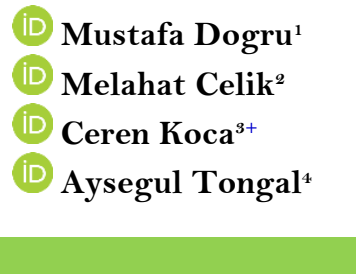

Article History

Received: 27 December 2021

Revised: 31 January 2029

Accepted: 14. February 2029

Published: 24 February 2022

\section{Keywords}

Life

Career skills

Flexibility

Adaptability

Entrepreneurship

Self-management

Productivity

Accountability

Leadership

Responsibility.

\author{
${ }^{1,2,4}$ Department of Science Education, Akdeniz University, Turkey. \\ 'Email: mustafadogru@akdeniz.edu.tr Tel: +9005075016713 \\ ${ }^{2}$ Email: melahat.celik.514@gmail.com Tel:+9005346688834 \\ ${ }^{4}$ Email: tongalaysegul@gmail.com Tel: +9005079760401 \\ ${ }^{3}$ Department of Child Development, Akdeniz University, Turkey. \\ ${ }^{s}$ Email: cerenkoca@akdeniz.edu.tr Tel: +9005071563222
}

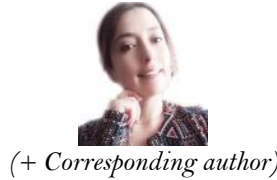

Contribution/ Originality: Although there are many 21 st century skill scales in the literature, life and career skills scales are limited. In this context, this study is an important contribution to the literature as it measures the life and career skills of university students.

\section{INTRODUCTION}

Although there is a general tendency in the literature about what 21 st-century skills are, there are also different opinions. According to $\mathrm{P} 21$, Partnership for 21 st Century Learning, which is a national nonprofit organization advocating for 21 st century skills in the classroom, these skills include several key elements and they are divided into the 4 C's of 21 st century learning: critical thinking, collaboration, communication and creativity (Partnership for 21 st Century Learning, 2020). In the literature, the general framework of 21 st-century skills known as $\mathrm{P}_{2} 1$ is shown in Figure 1.

As shown in Figure 1, $\mathrm{P}_{2} 1$ includes key subjects (3Rs: English, reading and language arts, world languages, arts, mathematics, economics, science, geography, history, government, and civic knowledge), i) learning that consists of three main skill areas referred to as innovation skills, ii) knowledge, media, and technology skills and iii) life and career skills (Partnership for 21 st Century Learning, 2020).

21 st century skills are the skills that facilitate the adaptation of the individual to change, develop the structure of resilience, produce projects, and achieve productive results, create awareness against global problems as well as individual rights and freedoms within the framework of mutual respect. These skills form the basis of a society 
consisting of individuals with a high sense of duty and responsibility. In addition to this, these skills are the embodiment of the understanding of society for the individual, which highlights the basic features of the information age (Partnership for 21 st Century Learning, 2020).

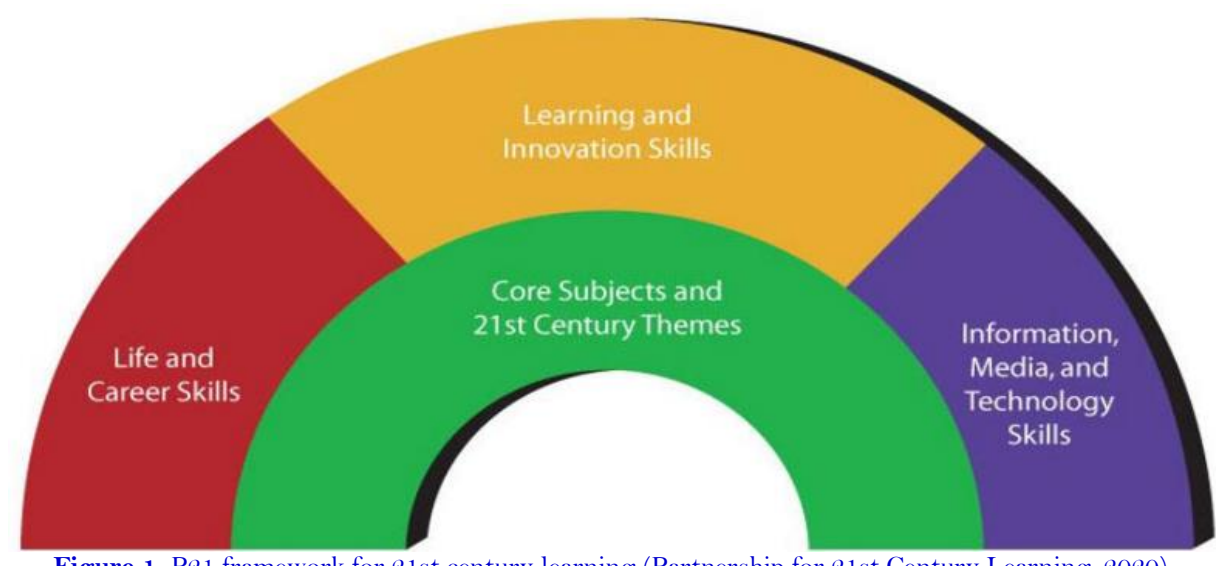

Figure 1. P21 framework for 21st century learning (Partnership for 21st Century Learning, 2020).

The first of life and career skills is flexibility and adaptability. In a world where great changes are constantly experienced, being able to adapt to changing conditions by showing flexibility is one of the basic conditions of existence. Being adaptable is being able to manage many tasks and priorities by assuming multiple responsibilities. In this context, flexibility and adaptability provide the balance between the individual's beliefs and reactions in changing conditions. Especially today, in the face of the rapid development of technology, individuals need to be in a position to keep up with the change. Otherwise, manipulation of the competitive open market of the global business world will be inevitable (Trilling \& Fadel, 2009). In addition to these, self-management is one of the important skills to use time efficiently. In addition, self-management is the process of using talents in the most efficient way within a value judgment based on lifelong learning, as well as skills such as managing time and goals well. Today, the workload of every individual is quite high. In order to fulfill these duties and responsibilities, each individual must have self-management skills (IOWA, 2013). Another skill type that forms an important part of this category is social skills. It has become a necessity for individuals of all age groups to work in harmony and in a productive way with their community (Partnership for 21 st Century Learning, 2020). Optimizing this coexistence is related to the social skills of the individual. Social skills are a set of behaviors that emerge from the interactions of individuals with each other. These behaviors include unobservable cognitive and affective elements that respond appropriately by analyzing and evaluating social information. In addition, social skills are the skills that enable the individual, who is a social being, to adapt to the society he lives in. These skills make the individual important to society because of the power that comes from interaction. Social skills form the basis for individuals to emphasize their values in society (Partnership for 21st Century Learning, 2020; Trilling \& Fadel, 2009).

Productivity and accountability, the other important skills in this category, are intertwined and complementary skills. Productivity is the ability to create products with work that foresees ethics and cooperation within the concept of effective time management by determining needs in line with the objectives. Accountability is assuming a role in the product creation process and being responsible for the effectiveness of the product. Productivity and accountability skills, which are closely related to creating projects with the expected level of efficiency for individuals of the information age, and getting results from the projects created, are among the essential skills of the 21 st century that should be employed in the business world and should be acquired during education (Kivunja, 2015). On the other hand, leadership is the ability to direct individuals towards certain goals and to mobilize them to achieve these goals. Thanks to the right leadership skills, the individual has the characteristics such as being able to keep up with the change in every field such as education and the competitive business world and eliminating 
negative situations such as stress and loss of motivation caused by change. A good leader is the person who makes sure his group is successful by creating opportunities by using all available options effectively. Leaders putting their thoughts into action have the competence to resolve disagreements through consensus and turn obstacles into innovations (Partnership for 21 st Century Learning, 2020). When the relevant literature is examined, it is seen that scale development / adaptation studies are carried out to determine the 21 st century skills of students studying at many educational levels; primary school students (Boyaci \& Atalay, 2016), secondary school students (Ball, Joyce, \& Anderson-Butcher, 2016; Kang, Kim, Kim, \& Ve You, 2012; Karakaş, 2015; Ongardwanich, Kanjanawasee, \& Tuipae, 2015), secondary school and high school students (Kang, Heo, Jo, Shin, \& Seo, 2010), high school students (Arsad, Osman, \& Soh, 2011; Osman, Soh, \& Arsad, 2010), high school and university students (Cevik \& Senturk, 2019), university students (Yılmaz \& Alkıs, 2019), teacher candidates (Anagun, Atalay, Kılıc, \& Yasar, 2016; Tondeur et al., 2017). Apart from these studies, Jia, Oh, Sibuma, LaBanca, and Lorentson (2016) conducted a scale development study to measure pre-service teachers 'and teachers' self-efficacy perceptions about teaching $21 \mathrm{st}$ century skills. In the light of all this information, it is seen that there are many scale development studies for 21 st century skills, but there are not enough studies to measure life and career skills. As a result, this study aims to investigate the psychometric properties of the scale for university students, to create a measurement model for life and career skills, and to develop a life and career skills scale. In addition, information from this measure helps students explore their strengths and disadvantages in the context of life and career skills.

\section{METHOD}

The data of this study were collected by using the scanning model. The scanning model aims to collect data to determine certain characteristics of a group (Büyüköztürk, Kılıc-Cakmak, Akgün, Karadeniz, \& Demirel, 2019). The convenience sampling technique was used during the selection of the sample in the study. Convenience sampling is the method of selecting the sample from accessible, easily applicable units due to the limitations in terms of time, money and labor (Büyüköztürk et al., 2019).

\subsection{Study Group}

In the study, life and career skills scale development phase of the study group was conducted during the fall semester of the 2020-2021 academic year, when students constitute ongoing study in universities in Turkey. Data were collected from 396 students to determine the factor structure of the scale and from 439 students to verify this structure. In determining the factor structure of the scale, the steps of developing a scale were applied to the first study group. As a matter of fact, it is known that the sample size of 200 people will generally be sufficient as an absolute criterion to extract reliable factors, and this figure can be reduced to 100 in cases where the factor structure is clear and small, but it will be more appropriate to work with a large sample (Kline, 1994). In this case, it can be said that the sample is suitable enough for this study.

\subsection{Steps Followed in the Scale Development Process \\ 2.2.1. Creating the Item Pool}

The development of the life and career skills scale was started by creating an item pool. First of all, measurement tools related to life and career skills have been examined in the literature. Then, 63 items were written. 11 of these items were listed as negative items. While writing the factors, care was taken to include equal number of items in each factor.

\subsubsection{Taking Expert Opinion}

The "Life and Career Skills Scale Draft Form" was examined by four experts in the field of professional development, two of them in the field of assessment and evaluation, and the other two ones in the field of Turkish 
Education. Experts were asked to score the accuracy of each item in terms of suitability to the level of university students, its relevance to life and career skills, language and expression, considering the items specified in the form. Scoring was made as Not Suitable (1), Partially Suitable (2), and Suitable (3). A 63-item trial form was created after the necessary corrections were made following the opinions of the subject experts.

\subsubsection{Pre-Trial Application}

A pre-application was conducted with 25 university students to check whether the items in the "Life and Career Skills Scale Draft Form" were understood by students. During the pre-application phase, the students were asked questions about the understandability of the items. In line with the feedback provided by the students at this stage, linguistic corrections were made on the items determined and the scale was made ready for the actual application.

\subsection{Data Analysis}

After the necessary corrections and pre-elimination, the scale consisting of 63 items was prepared in 5-point Likert type. The score distribution of the positive sentences is "Strongly Agree $=5$ points", "Agree 4 points", "Partially Agree = 3 points", "Disagree = 2 points" and "Strongly Disagree = 1 point".

There are different opinions in the literature regarding whether the data are suitable for factor analysis. Some researchers suggest that the sample size should not fall below 100, while others mention that this number should exceed five times the number of items (Ho, 2006). Within the scope of the research, the sample size, which was deemed important for factor analysis, was examined and the study group was deemed sufficient.

In the study, item analysis method based on item scale total correlation was used to determine the items to be included in the scale. This is one of the recommended methods in the scale development process (Tavsancil, 2006). Kaiser-Meyer-Olkin (KMO) and Bartlett sphericity tests were conducted for the suitability of the research data to factor analysis.

The fact that KMO has a value greater than 0.60 and close to 1 and the Barlett test is significant indicates that the data are suitable for factor analysis (Buyukozturk, 2018; Tabachnick \& Fidell, 2001). Exploratory factor analysis (EFA) and confirmatory factor analysis (CFA) were performed to determine the construct validity of the scale. The Cronbach's Alpha $(\alpha)$ coefficient was used to determine the reliability level of the scale and, finally, simple correlation analysis was used for the relationship between the dimensions of the scale and the overall results. The data of the study were analyzed using SPSS 20 and LISREL 8.80 statistical package programs.

\section{RESULTS}

\subsection{Factor Analysis (Structure Validity)}

In scale development studies, the most frequently used method to reveal the construct validity of a scale is factor analysis (Secer, 2017). Factor analysis is a statistical method that brings together a large number of interrelated variables and reveals fewer and meaningful new variables (Buyukozturk, 2018). The factor analysis technique used to reveal the construct validity of the life and career skills scale was performed by going through the following stages.

\subsection{Sampling Appropriateness for Factor Analysis KMO Coefficient and Bartlett's Test of Sphericity}

Sampling appropriateness for factor analysis KMO Coefficient and Bartlett's Test of Sphericity are shown in Table 1 .

According to the findings in Table 1, the result is perfect because the KMO coefficient is .906. Therefore, the sample size in the research is sufficient. Another test required to apply factor analysis to a data set is the sphericity test, which tests the main mass integrity, and it was developed by Bartlett. In factor analysis, a high correlation relationship is sought between variables. In this sense, the Bartlett test is used to test whether there is a significant 
relationship between the variables in the data set (Tabachnick \& Fidell, 2001). According to the findings in Table 1 $\left(\mathrm{X}_{2}=3076.894 ; \mathrm{df}=190 ; \mathrm{P}<0.01\right)$ Bartlett Sphericity Test was a success. According to these values, it can be said that the data are suitable for factor analysis.

Table 1. Kaiser-meyer-olkin (KMO) and bartlett sphericity test results of the scale.

\begin{tabular}{l|l|r}
\hline Kaiser-Meyer-Olkin (KMO) Value & \multicolumn{2}{|c}{0.906} \\
\hline \multirow{3}{*}{ Bartlett's test of sphericity } & Chi-square $\left(\mathrm{x}^{2}\right)$ & 3076.894 \\
\cline { 2 - 3 } & Df $(\mathrm{sd})$ & 190 \\
\cline { 2 - 3 } & Sig $(\mathrm{p})$ & 0.000 \\
\hline
\end{tabular}

\subsection{Explanatory Factor Analysis Result}

The factor analysis study of the Life and Career Skills Scale was conducted by applying the Principle Component Analysis technique, which aims to reduce variables and reach at meaningful conceptual structures. the eigenvalue and variance analysis of the factors and the line graph (Scree plots) were examined together in order to strengthen this study and to make the right decision on the number of factors. Eigenvalue shows the total variance explained by a factor (Karagoz \& Kösterelioğlu, 2008). Accordingly, factors with an eigenvalue greater than 1 are considered as appropriate for the analysis (Altunışık, Coskun, Bayraktaroğlu, \& Yıldırım, 2005).

The Varimax Vertical Rotation Technique was used in order to gather items with high correlation in a factor (Buyukozturk, 2018). According to the result of the principal components analysis performed in the factor analysis and the rotation using the Varimax Technique, 15 factors with an eigenvalue greater than 1.00 emerged. Due to the overlapping of the factor loads examined and the presence of items that do not measure the same structure, it was decided to remove inappropriate items. The criteria for removing unsuitable items are as follows:

a- After the items in the factor were rotated, the 46th, 45th and 57 th items were removed from the scale as the load values were lower than .40 (Stevens, 1996).

b- If it is found in more than one factor and has a high load value and is lower than .10 (Hinkin, 1998; Tabachnick \& Fidell, 2001), 42, 16, 38, 48, 60, 33, 50, 32, Items 20, 13, 6, 37, 54, 7, 12, 23, 26, 35, 39, 61, 62, 11, 47,59 and 31 were excluded from the scale.

c- Items $1,55,19,21,8,34,5$, and 2 which constitute a factor of one or two items were also removed from the scale.

d- Items 3, 4, 24, 25, 28 and 29, whose load values are lower than .30 in the scale's total correlation of the items, were also removed from the scale.

d- Finally, item 27 which was below the unsuitable factor was removed from the scale.

After removing inappropriate items from the resulting factor structure, a 20-item Life and Career Skills Scale with 4 factors, which explain $58.384 \%$ of the total variance, was created. The eigenvalue and variance analysis results of the factor analysis are shown in Table 2.

Table 2. Eigenvalues of the factors of the scale and their explained variance percentages.

\begin{tabular}{c|c|c|c|c|c|c}
\hline \multirow{2}{*}{ Factor } & \multicolumn{3}{|c|}{ Initial Eigenvalues } & \multicolumn{3}{c}{ Variance Explained } \\
\cline { 2 - 7 } & Total & Variance\% & Cumulative\% & Total & Variance\% & Cumulative\% \\
\hline 1 & 6.922 & 34.610 & 34.610 & 3.665 & 18.325 & 18.325 \\
\hline 2 & 1.963 & 9.817 & 44.427 & 2.788 & 13.940 & 32.265 \\
\hline 3 & 1.501 & 7.505 & 51.933 & 2.781 & 13.903 & 46.168 \\
\hline 4 & 1.290 & 6.451 & 58.384 & 2.443 & 12.216 & 58.384 \\
\hline
\end{tabular}

In Table 2, the eigenvalues of the factors of the life and career skills scale and the variance percentages they explain are shown. According to the result of the eigenvalue analysis, it was found that the 1st factor got a result of6.922, the 2 nd factor got 1.963, the 3rd factor got 1.501 and the 4th factor got 1.290. When the eigenvalues of the 
factors of the scale were examined, it was seen that the eigenvalue of the scale consisted of 4 factors greater than 1. After the eigenvalue analysis of the scale, the variance explained by the factors of the scale was examined. Accordingly, it has been revealed that the 1 st factor explains $18.325 \%$ of the total variance, the 2 nd factor explains $13.940 \%$, the 3rd factor explains $13.903 \%$ and the 4 th factor explains $12.216 \%$ of the total variance. It was determined that the life and career skills scale consists of 4 factors and these explained $58.384 \%$ of the total variance. It is considered as sufficient if the variance explained in social sciences is between $40 \%$ and $60 \%$ (Tavsancil, 2005). In this case, it can be said that the total variance is sufficient for this study.

Another criterion to be considered after the eigenvalue and variance percentages in order to determine the factor number of the scale to be developed is the line plot. In Figure 2, a line chart (Scree Test Chart) of factor eigenvalues is given.

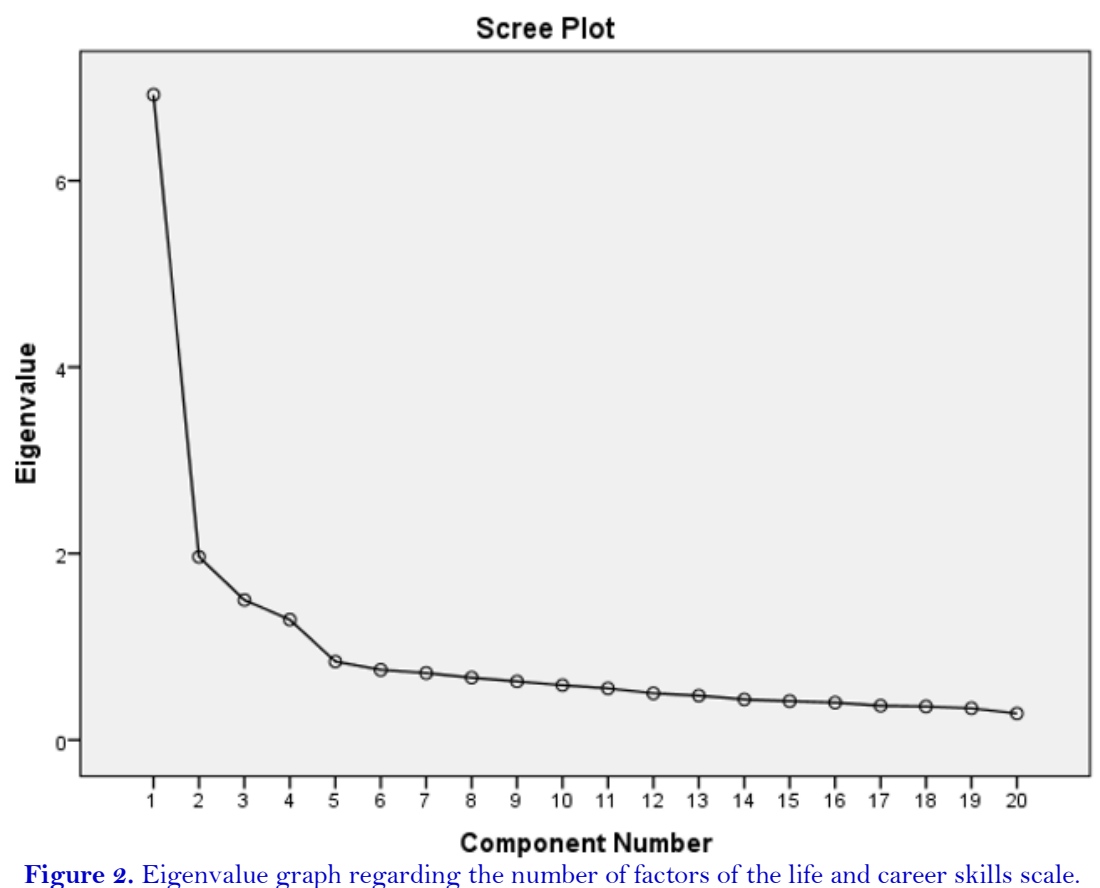

In the eigenvalue graph of the scale given in Figure 2, the interval between both points represents a factor. It demonstrates a high level of acceleration for factors and rapid declines in the eigenvalue graph (Cokluk, Sekercioğlu, \& Büyüköztürk, 2016). Based on this information, in the line graph of the scale, it was determined that there was a decrease in the slope of the line and a balanced position at the 4th point. As a result, it was observed that the eigenvalue line graph results and the results of the eigenvalue and variance analysis coincided, and the scale had a four-factor structure.

\subsection{Factor Items of the Scale and Item Scale-Total Correlations}

After determining the factor structure of the Life and Career Skills Scale, it was examined which items will be included under which factor. The factors obtained as a result of the exploratory factor analysis made over the remaining 20 items after the unsuitable items were removed as a result of the examination, the factor loadings of the items collected under these factors and the scale total correlations of the items are shown in Table 3.

When the analysis results in Table 3 were examined, it was seen that the items after rotation were grouped under 4 factors. As seen in Table 3, factor load valuesrangebetween.788 and.550 for factor 1, between 0.766 and 0.703 for factor 2 , between 0.766 and 0.546 for factor 3, and finally between 0.807 and 643 for factor 4 . When the factor load values are examined in terms of magnitude, it is possible to characterize the load values from "good" to "excellent" (Cokluk et al., 2016). 
Table 3. Factor loads and item scale-total correlations in the life and career skills scale.

\begin{tabular}{|c|c|c|c|c|c|c|}
\hline \multirow{2}{*}{$\begin{array}{l}\text { Item } \\
\text { No. }\end{array}$} & \multirow[t]{2}{*}{ Item Statement } & \multicolumn{4}{|c|}{ Load Values After Rotation } & \multirow{2}{*}{$\begin{array}{c}\begin{array}{c}\text { Item Scale-Total } \\
\text { Correlation }\end{array} \\
\mathbf{r}\end{array}$} \\
\hline & & Factor-1 & Factor-2 & Factor-3 & Factor-4 & \\
\hline 15 & I can manage my time. & 0.788 & & & & 0.461 \\
\hline 44 & $\begin{array}{l}\text { I prefer to plan my time during the } \\
\text { day. }\end{array}$ & 0.741 & & & & 0.377 \\
\hline 63 & $\begin{array}{l}\text { I cannot plan the time well while } \\
\text { running my business. }\end{array}$ & -0.723 & & & & -0.522 \\
\hline 36 & $\begin{array}{l}\text { I manage my time and Projects } \\
\text { effectively. }\end{array}$ & 0.679 & & & & 0.600 \\
\hline 17 & $\begin{array}{l}\text { I set goals for myself and work in } \\
\text { line with my goals. }\end{array}$ & 0.674 & & & & 0.546 \\
\hline 22 & $\begin{array}{l}\text { When I find it difficult to do a job, I } \\
\text { look for other ways to engage } \\
\text { myself. }\end{array}$ & 0.584 & & & & 0.550 \\
\hline 14 & $\begin{array}{l}\text { I can guide myself while learning } \\
\text { new information. }\end{array}$ & 0.550 & & & & 0.585 \\
\hline 10 & $\begin{array}{l}\text { I have no trouble adapting to } \\
\text { different environments. }\end{array}$ & & 0.766 & & & 0.521 \\
\hline 18 & $\begin{array}{l}\text { I can have open and sincere } \\
\text { relationships with people. }\end{array}$ & & 0.733 & & & 0.494 \\
\hline 9 & $\begin{array}{l}\text { I can develop behaviors suitable for } \\
\text { my new environment. }\end{array}$ & & 0.703 & & & 0.529 \\
\hline 30 & I enjoy meeting new people. & & 0.703 & & & 0.520 \\
\hline 56 & $\begin{array}{l}\text { I determine the duties and } \\
\text { responsibilities of group members in } \\
\text { group work. }\end{array}$ & & & 0.766 & & 0.493 \\
\hline 52 & $\begin{array}{l}\text { I use problem solving skills in the } \\
\text { group. }\end{array}$ & & & 0.746 & & 0.625 \\
\hline 51 & $\begin{array}{l}\text { I use interpersonal skills to guide a } \\
\text { group. }\end{array}$ & & & 0.707 & & 0.626 \\
\hline 49 & $\begin{array}{l}\text { I plan activities for the community } \\
\text { of which I am a member to achieve } \\
\text { its goals. }\end{array}$ & & & 0.626 & & 0.607 \\
\hline 58 & I motivate the group in group work. & & & 0.546 & & 0.522 \\
\hline 41 & $\begin{array}{l}\text { I present my work with in the } \\
\text { framework of appropriate etiquette. }\end{array}$ & & & & 0.807 & 0.504 \\
\hline 43 & $\begin{array}{l}\text { I try to do my job in the best way } \\
\text { possible. }\end{array}$ & & & & 0.709 & 0.460 \\
\hline 40 & I follow ethical rules while working. & & & & 0.691 & 0.392 \\
\hline 53 & $\begin{array}{l}\text { I respect the rights and } \\
\text { responsibilities of others while using } \\
\text { my own rights. }\end{array}$ & & & & 0.643 & 0.350 \\
\hline
\end{tabular}

Note: Variance Explained.

Total: \%58,384

Factor-1: \%18,325

Factor-2: \%13,940

Factor-3: \%13,903

Factor-4 \% 12,216

The contribution of factors to variance was found to be $18.325 \%$ for factor $1,13.940 \%$ for factor $2,13.903 \%$ for factor 3 , and finally $12.216 \%$ for factor 4 . The total contribution of the four factors determined to the variance is $58.384 \%$. In multi-factor designs, it is considered sufficient if the variance explained is between $40 \%$ and $60 \%$ (Cokluk et al., 2016). It is seen that the contribution of a factor defined in this framework to the total variance is sufficient. In Table 4, 4 factors emerging as a result of the exploratory factor analysis, the items in these factors and the names of the factors are included.

When the factors of the scale in Table 4 and the items under these factors were examined, it was seen that the scale consisted of 4 factors and 20 items, consisting of 7 items in the $1^{\text {st }}$ factor, 4 items in the $2^{\text {nd }}$ factor, 5 items in the $3^{\text {rd }}$ factor, and 4 items in the $4^{\text {th }}$ factor. According to the factors created based on the literature and the items 
under these factors, the items under the $1^{\text {st }}$ factor are "Entrepreneurship and Self-Management", the ones under the $2^{\text {nd }}$ factor are "Flexibility and Adaptability", the ones under the $3^{\text {rd }}$ factor are "Leadership and Responsibility" and the items under the $4^{\text {th }}$ factor are "Productivity and "Accountability" factors. While creating the item pool, a 5factor structure and items were prepared, but items under the "Social and Intercultural Interaction" factor did not work at the EFA stage, so these items were removed. The final version of the scale represents a 4-factor structure consisting of 20 items. After determining the factors and items under these factors of the Life and Career Skills Scale, the reliability studies of the scale were initiated.

Table 4. The factors of the scale as a result of the exploratory factor analysis, the items and factor names in these factors.

\begin{tabular}{l|c|c}
\hline Factors & Item Count & Items \\
\hline 1.Factor 1 (Entrepreneurship and Self-Government) & 7 & $15,44,63,36,17,22,14$ \\
\hline 2. Factor 2 (Flexibility and Adaptability) & 4 & $10,18,9,30$ \\
\hline 3. Factor 3 (Leadership and Responsibility) & 5 & $56,52,51,49,58$ \\
\hline 4. Factor 4 (Productivity and Accountability) & 4 & $41,43,40,53$ \\
\hline
\end{tabular}

\subsection{Cronbach Alpha Internal Consistency Coefficient}

If the Cronbach Alpha coefficient, which is the measure of internal consistency, is below 0.40, the scale is "Unreliable", if it is between 0.40-0.59, the scale has "Low Reliability", a value between 0.60-0.79 is "Highly Reliable" and if it is between 0.80-1.00, this states that the scale is "Highly Reliable" (Tavsancil, 2005). In this study, the internal consistency of the life and career skills scale for university students was examined by calculating the Cronbach's alpha values for the whole scale and the four sub-factors created. The results of the analyzes made are given in Table 5 .

Table 5. Cronbach alpha internal consistency coefficient of the factors of the scale.

\begin{tabular}{c|c}
\hline Factors & Cronbach Alpha \\
\hline Factor 1 & 0.501 \\
\hline Factor 2 & 0.781 \\
\hline Factor 3 & 0.819 \\
\hline Factor 4 & 0.731 \\
\hline Total & 0.844 \\
\hline
\end{tabular}

According to the analysis of the data in Table 5, when the Cronbach Alpha reliability coefficients of the subfactors of the life and career skills scale for university students are examined, these coefficients are respectively 0.501 for Factor 1, 0.781 for Factor 2, 0.819 for Factor 3, and finally 0.731 for Factor 4. Cronbach Alpha reliability coefficient of these 20 items in the scale is 0.844 . A Cronbach's alpha value of 0.70 and above is considered sufficient for the reliability of the measuring tool, and the measurement tool that meets this value is considered reliable (Buyukozturk, 2018). Accordingly, it can be said that the $2^{\text {nd }}, 3^{\text {rd }}$ and $4^{\text {th }}$ factors have high reliability, and the $1^{\text {st }}$ factor has low reliability. Considering this outcome, it can be said that the scale is quite reliable. The correlation between the factors of life and career skills scale of university students was examined and the results are shown in Table 6 .

Table 6. Results of pearson moments multiplication correlation coefficient performed to determine the relationships between the dimensions of the scale.

\begin{tabular}{c|c|c|c|c|c}
\hline Factors & Factor-1 & Factor -2 & Factor -3 & Factor -4 & Scale \\
\hline Factor-1 & 1.00 & 0.403 & 0.503 & 0.363 & 0.785 \\
\hline Factor-2 & & 1.00 & 0.519 & 0.372 & 0.755 \\
\hline Factor-3 & & & 1.00 & 0.436 & 0.831 \\
\hline Factor-4 & & & 1.00 & 0.644 \\
\hline
\end{tabular}


As indicated in Table 6 , it is seen that there is a significant relationship between the factors that emerged as a result of the exploratory factor analysis and there is no multiple connection problem. High correlation coefficient is between 0.70-1.00 absolute value; when between 0.70-0.30, it is medium; if it is between 0.30-0.00, it can be defined as a low level relationship (Buyukozturk, 2018).

It is seen that there is a high and medium level of correlation between the total scale score and the factors, and a high and medium level of correlation between the factors themselves. The results obtained can be shown as evidence of construct validity.

\subsection{Confirmatory Factor Analysis (CFA)}

It was revealed by EFA that Life and Career Skills Scale consists of 4 factors and 20 items. CFA was applied to the structure created to determine the accuracy of the structure revealed as a result of EFA. While the purpose of EFA is to reveal a new structure by revealing the relationship between data, the purpose of DFA is to statistically determine whether this structure emerged with EFA is verified or not (Can, 2019; Secer, 2017).

Many fit indexes are used in order to reveal the adequacy of the Life and Career Skills Scale with the structural model CFA. The fit indexes examined in this study are Chi-Square Goodness Test, GFI (Goodness of Fit Index), RMSEA (Root Mean Square Error of Approximation), CFI (Comparative Fit Index), NFI (Normed Fit Index), RFI (Relative Fit Index), IFI (Incremental Fit Index) and AGFI (Adjusted Goodness of Fit Index) (Kline, 2005; Schumacker \& Lomax, 2004; Simsek, 2007).

For CFI, NFI, NNFI, RFI and IFI indexes, the perfect fit value is 0.95 and above, while the acceptable fit value is 0.90 and above. For GFI and AGFI indexes, 0.90 and above is the perfect fit index, while the $0.85-0.90$ limit range is seen as the acceptable fit value. For RMSEA, perfect fit is between 0.00-0.050 whereas the acceptable fit limit is between 0.050-0.080 (Schumacker \& Lomax, 2004). The fit index values of the 4-factor model were examined with CFA and shown in Table 7 and Figure 2 for CFA.

Table 7. Values on goodness of fit tests for life and career skills.

\begin{tabular}{c|c|c|c|c|c|c|c|c|c|c|c}
\hline $\boldsymbol{X}^{2}$ & $\boldsymbol{X}^{q} / \boldsymbol{d} \boldsymbol{f}$ & P-Value & NFI & NNFI & RFI & CFI & GFI & AGFI & SRMR & IFI & RMSEA \\
\hline 584.75 & 3.56 & 0.000 & 0.94 & 0.95 & 0.93 & 0.96 & 0.88 & 0.85 & 0.073 & 0.96 & 0.077 \\
\hline
\end{tabular}

According to the CFA results in Table 7, the ratio of the chi-square value to the degree of freedom $\left(\mathrm{X}^{2} / \mathrm{df}\right)$ being less than 5 indicates that it is an acceptable fit value (Anderson \& Gerbing, 1984; Sumer, 2000). $\mathrm{X}^{2}=584.75$, $\left.\mathrm{sd}=164, \mathrm{X}^{2} / \mathrm{df}=3.56, \mathrm{p}=0.000\right)$ were found to be significant.

The CFI, IFI and NNFI values of 0.95 and above, which are among the other fit indexes that should be examined, indicate that there is a perfect fit, while GFI and AGFI values between 0.85-0.90 and the RFI value between 0.90-0.95 indicate that there is an acceptable fit (Schumacker \& Lomax, 2004). Among the fit indexes, SRMR and RMSEA values were found to be within the acceptable fit limit which is between 0.050-0.080 (Anderson \& Gerbing, 1984; Hu \& Bentler, 1999; Schumacker \& Lomax, 2004).

The fit index values obtained as a result of CFA for the Life and Career Skills Scale show that they confirm the structure consisting of 4 factors and 20 items. No modification was needed between the items, as the CFA made showed that the model fit well. The standardized path diagram, factors and $t$ values between items have been examined for the level of representing the factor in which the items in each dimension of the scale are shown, and are shown in Figure 3 and Figure 4. 


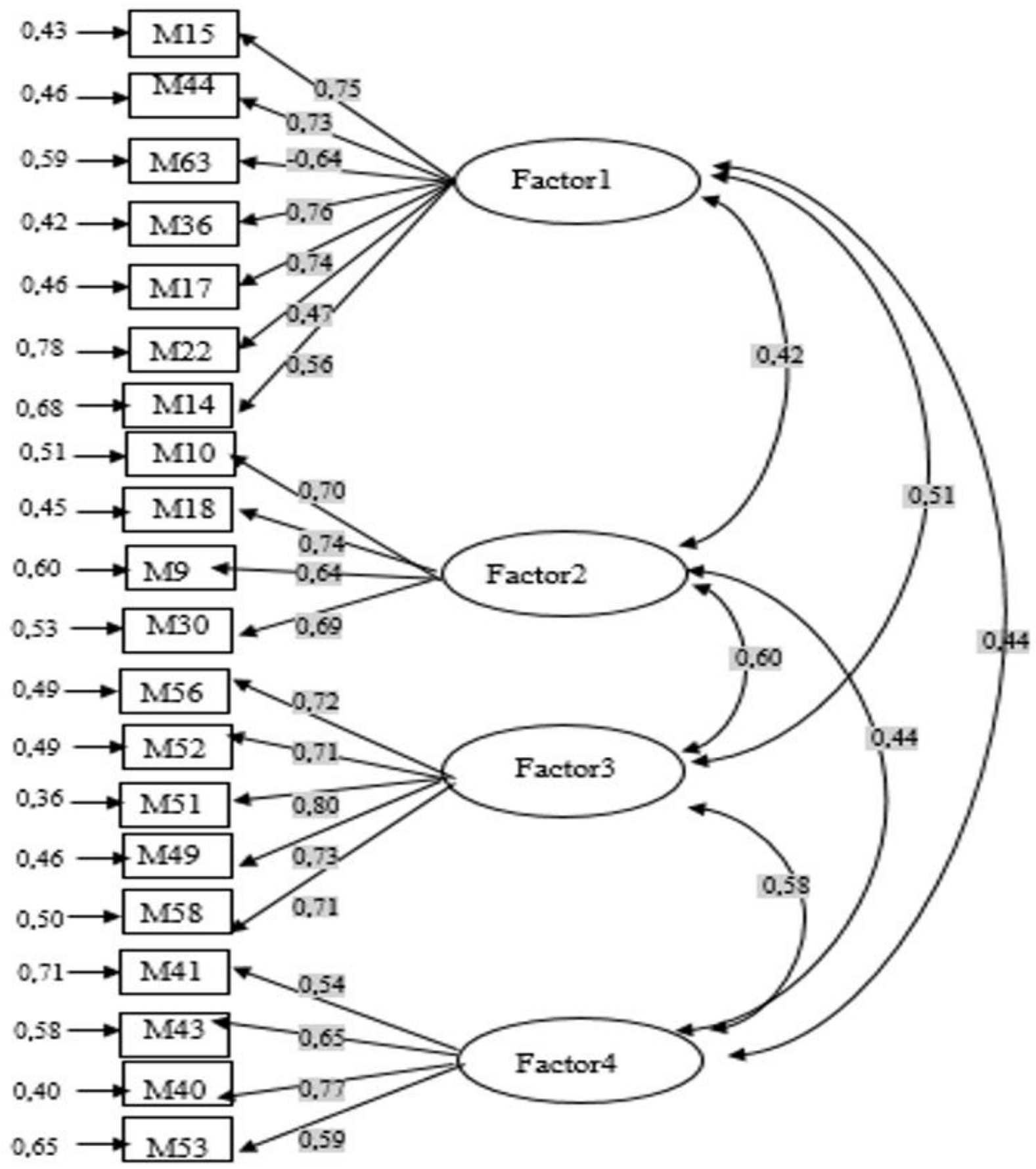

Figure 3. DFA results of the scale: Standardized path diagram. Note: chi Square $=584.75, \mathrm{df}=164, \mathrm{p}$ value $=0.00000, \mathrm{RMSEA}=0.077$

Factor loadings of the scale in Figure 3 are between 0.47 and 0.76 for the 1 st factor, between 0.64 and 0.74 for the 2 nd factor, between 0.71 and 0.80 for the 3rd factor, and between 0.54 and 0.77 for the 4th factor, which is the last one. In the standardized path diagram, the factor structure of the scale and the load values of each item are included. The desired situation for the load values to be is 0.30 and above (Secer, 2017). According to Figure 3, it is seen that all factor load values are above 0.30. After the standard values of the scale, $t$ values were examined. The $t$ values obtained with DFA are shown in Figure 4. Jöreskog and Sorbom (1996) state that it is necessary to examine whether there is a red arrow when examining t values. In this case, it shows that all items that do not have red arrows in the $t$ values among the factors and items in Figure 4 are significant at 0.05 level. 


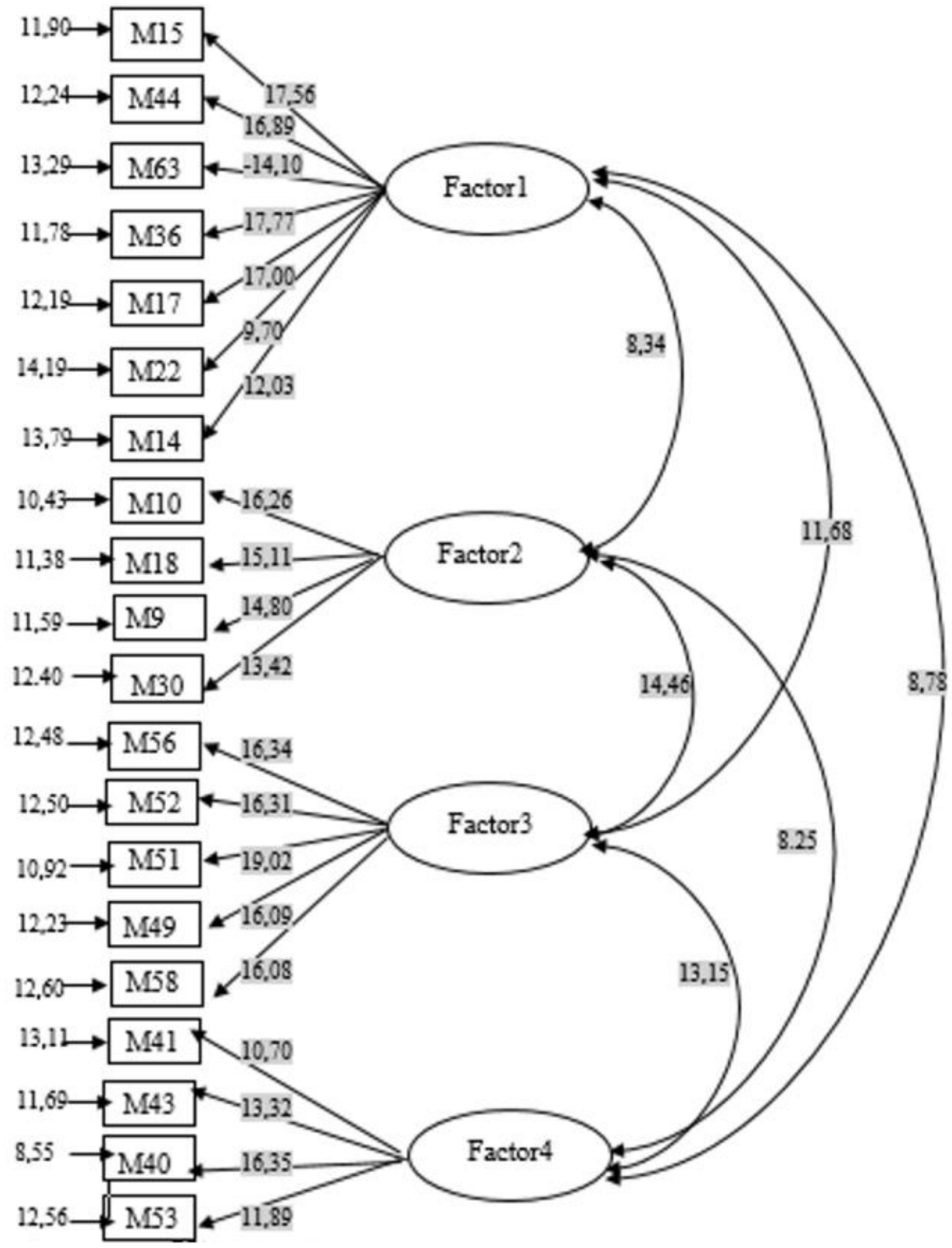

Figure 4. DFA results of the scale: $\mathrm{T}$ values.

Note: chi Square $=584.75, \mathrm{df}=164, \mathrm{p}$ value $=0.00000, \mathrm{RMSEA}=0.077$.

\section{CONCLUSION}

The Life and Career Skills Scale was developed to measure university students' life career skills considered within the context of 21 st Century Skills. During the development of the scale, the relevant literature was scanned in detail and in about 3 weeks, the subcategories of life and career skills which are "Flexibility and Adaptability", "Entrepreneurship and Self-Management", "Productivity and Accountability", and "Leadership and Responsibility", 63 items consisting of 5 factors as "Social and Intercultural Interaction" were written.

The items written were arranged according to the expert opinion form and presented to the experts for their opinion. The items were rearranged in line with the recommendations of the experts and the scale was finalized. Data were collected from 396 university students for the scale, which is ready for implementation, and EFA was performed by transferring the data to electronic environment for appropriate analysis. In accordance with the result of EFA, a 20-item scale structure consisting of 4 factors was obtained. The obtained factors were organized under 
the titles "Flexibility and Adaptability", "Entrepreneurship and Self-Management", "Productivity and Accountability" and "Leadership and Responsibility". While writing the scale items, 5 factors were considered, and this number was reduced to 4 , since the items related to the 5th factor "Social and Intercultural Interaction" did not work properly. Items related to flexibility and fit; While the variance ratio explained was $18.325 \%$, the items were $10^{\text {th }}, 18^{\text {th }}, 9^{\text {th }}$ and $30^{\text {th }}$, while the factor loads of the items varied between. The items related to entrepreneurship and self-management were 15, 44, 63, 36, 17, 22 and 14 and item 63 was a negative item. In addition, the variance rate explained by this factor is $13.940 \%$, and it has been revealed that the factor loads of the items vary between .766 and .703. The items related to productivity and accountability were $41,43,40$ and 53 , and the variance ratio they explain is $13.903 \%$, while the factor loadings of the items vary between .766 and. Finally, the items related to leadership and responsibility were items 56,52,51,49 and 58, and the variance ratio they explained was $12.216 \%$, while the factor loadings of the items were between .807 and .643 . The total variance rate explained by the scale was calculated as $58.384 \%$. A variance rate between $40 \%$ and $60 \%$ explained in scale development studies in social sciences is considered sufficient (Buyukozturk, 2018; Tavsancil, 2005).

Accordingly, the variance ratio explained by the scale was thought to be sufficient. Item analysis of the scale revealed that the items in the scale were valid. The correlation between the factors of the scale and the correlation of the factors with the whole scale was examined, and the flexibility and adaptability factor was highly correlated with a value of 0.781 , the entrepreneurship and self-management factor had a moderate level of relationship. For the leadership and responsibility factor, it has been calculated that there is a high relationship with 0.819. The correlation calculated for the overall scale revealed a high correlation with 0.844 . Correlation coefficients between 0.30 and 0.70 are defined as "Moderate Relationship", and between 0.70-1.00 as "High Degree Relationship" (Buyukozturk, 2018). The ratio of the chi-square value obtained by CFA to the degree of freedom ( $\left.\mathrm{X}^{2} / \mathrm{df}\right)$ is less than 5, indicating that it is an acceptable fit value (Anderson \& Gerbing, 1984; Sumer, 2000), so the value $\mathrm{X}^{2} / \mathrm{df}=$ 3.56 is also acceptable. 0.95 and above of CFI (0.96), IFI (0.96) and NNFI (0.95) values, which are among the other fit indexes examined, indicate a perfect fit, GFI (0.88) and AGFI (0.85) values between 0.85 and 0.90. 93) value between 0.90-0.95 indicates that there is an acceptable fit (Schumacker \& Lomax, 2004). SRMR (0.073) and RMSEA (0.077) values of fit indexes were found to be within the acceptable fit limit which is between 0.050-0.080 (Anderson \& Gerbing, 1984; Hu \& Bentler, 1999; Schumacker \& Lomax, 2004).

Subsequently, a valid and reliable scale that can measure the life and career skills of university students has been put forward. This scale developed is intended for university students and may not be suitable for primary and secondary school study groups. For this reason, it is recommended to develop a measurement tool that can measure the life and career skills of primary and secondary school students. The final version of the scale for use in related studies has been added to the end of this study (Appendix A).

Funding: This study received no specific financial support.

Competing Interests: The authors declare that they have no competing interests.

Authors' Contributions: All authors contributed equally to the conception and design of the study.

\section{REFERENCES}

Altunışık, R., Coskun, R., Bayraktaroğlu, S., \& Yıldırım, E. (2005). Research methods in social sciences. Sakarya: Sakarya Bookstore.

Anagun, S. S., Atalay, N., Kılıc, Z., \& Yasar, S. (2016). For teacher candidates Development of 21 st century skills competence perceptions scale: Validity and reliability study. Pamukkale University Faculty of Education Journal, 40(40), $160-175$.

Anderson, J. C., \& Gerbing, D. W. (1984). The effect of sampling error on convergence, improper solutions, and goodness-of-fit indices for maximum likelihood confirmatory factor analysis. Psychometry, 49(2), 155-173.Available at: https://doi.org/10.1007/bfo2294170.

Arsad, N. M., Osman, K., \& Soh, T. M. T. (2011). Instrument development for 21 st century skills in Biology. Procedia-Social and Behavioral Sciences, 15, 1470-1474.Available at: https://doi.org/10.1016/j.sbspro.2011.03.312. 
Ball, A., Joyce, H. D., \& Anderson-Butcher, D. (2016). Exploring 21 st century skills and learning environments for middle school youth. International Journal of School Social Work, 1(1), 1-15.Available at: https://doi.org/10.4148/2 161-4148.1012.

Boyaci, S., \& Atalay, N. (2016). A scale development for 21 st century skills of primary school students: A validity and reliability study. International Journal of Instruction, 9(1), 133-148.Available at: https://doi.org/10.12973/iji.2016.911 1a.

Buyukozturk, S. (2018). Manual of data analysis for social sciences. Ankara: Pegem Academy.

Büyüköztürk, S., Kılıc-Cakmak, E., Akgün, O. E., Karadeniz, S. V., \& Demirel, F. (2019). Scientific research methods in education. Ankara: Pegem Academy.

Can, A. (2019). Quantitative data analysis in scientific research process with SPSS. Ankara: Pegem Academy.

Cevik, M., \& Senturk, C. (2019). Multidimensional 21st century skills scale: Validity and reliability study. Cypriot Journal of Educational Sciences, 14(1), 11-28.Available at: https://doi.org/10.18844/cjes.v14i1.3506.

Cokluk, O., Sekercioğlu, G., \& Büyüköztürk, S. (2016). Applications of multivariate statistics SPSS and LISREL for social sciences (4th ed.). Ankara: Pegem Academy Publishing.

Hinkin, T. R. (1998). A brief tutorial on the development of measures for use in survey questionnaires. Organizational Research Methods, 1(1), 104-121.Available at: https://doi.org/10.1177/109442819800100106.

Ho, R. (2006). Handbook of univariate and multivariate data analysis and interpretation with SPSS: Chapman and Hall/CRC.

Hu, L. t., \& Bentler, P. M. (1999). Cutoff criteria for fit indexes in covariance structure analysis: Conventional criteria versus new alternatives. Structural Equation Modeling: A Multidisciplinary Journal, 6(1), 1-55.Available at: https://doi.org/10.1080/10705519909540118.

IOWA. (2013). Department of education. Essential for 21 st century success. Retrieved from: www.educateiowa.gov/pk-12/iowacore/universal-constructsessential-2 1st-century-success.

Jia, Y., Oh, Y. J., Sibuma, B., LaBanca, F., \& Lorentson, M. (2016). Measuring twenty-first century skills: Development and validation of a scale for in-service and pre-service teachers. Teacher Development, 20(2), 229-252.Available at: https://doi.org/10.1080/13664530.2016.1143870.

Jöreskog, K. G., \& Sorbom, D. (1996). LISREL \& reference guide. Lincolnwood. IL: Scientific Software International.

Kang, M., Heo, H., Jo, I., Shin, J., \& Seo, J. (2010). Developing an educational performance indicator for new millennium learners. Journal of Research on Technology in Education, 43(2), 157-170.Available at: https://doi.org/10.1080/15391523.2010.10782567.

Kang, M., Kim, M., Kim, B., \& Ve You, H. (2012). Developing an instrumentomeasure 21 st century skills for elementary student. The Korean Journal of Educational Methodolocy Studies, 25(2).

Karagoz, Y., \& Kösterelioğlu, I. (2008). Development of communication skills assessment scale with factor analysis method. Dumlupinar University Journal of Social Sciences, 21, 81-98.

Karakaş, M. M. (2015). 21st grade science course for middle school eighth grade students. measuring century skill levels. Unpublished Master Thesis, Osmangazi University, Institute of Educational Sciences, Eskisehir, Turkey.

Kivunja, C. (2015). Teaching students to learn and to work well with 21 st century skills: Unpacking the career and life skills domain of the new learning paradigm. International Journal of Higher Education, 4(1), 1-11.Available at: https://doi.org/10.5430/ijhe.v4n 1p1.

Kline, P. (1994). An easy guide to factor analysis. London: Routledge.

Kline, R. B. (2005). Principles and practice of structural equation modeling: Methodology in The social sciences. New York: The Guilfrod Press.

Ongardwanich, N., Kanjanawasee, S., \& Tuipae, C. (2015). Development of 21 st century skill scales as perceived by students. Procedia-Social and Behavioral Sciences, 191, 737-741.Available at: https://doi.org/10.1016/j.sbspro.2015.04.716.

Osman, K., Soh, T. M. T., \& Arsad, N. M. (2010). Development and validation of the Malaysian 21 st century skills instrument (M-21CSI) for science students. Procedia-Social and Behavioral Sciences, 9, 599-603.Available at: https://doi.org/10.1016/j.sbspro.2010.12.204. 
Partnership for 21 st Century Learning. (2020). P21 framework definitions. Retrieved from; http://www.p21.org/our-work/p2 1framework.

Schumacker, R. E., \& Lomax, G. R. (2004). Beginner's guide to structural equation modeling. New Jersey: Lawrence Erlbaum Associates.

Secer, I. (2017). Practical data analysis with SPSS and LISREL. Ankara: Ani Publishing.

Simsek, O. F. (2007). Introduction to structural equation modeling: Fundamentals and Applications of LISREL. Ankara: Equinox.

Stevens, J. (1996). Applied multivariate statistics for the social sciences. New Jersey: Lawrence Erlbaum Associates Publishers.

Sumer, N. (2000). Structural equation models: Basic concepts and examples. Turkish Psychology Writings, 3(6), 74-79.

Tabachnick, B. G., \& Fidell, I. S. (2001). Using multivariate statistics (4th ed.). Bostan: Ally and Bacon.

Tavsancil, E. (2005). Measuring attitudes and data analysis with SPSS. Ankara: Nobel Publishing.

Tavsancil, E. (2006). Measuring attitudes and sata analysis with SPSS (3rd ed.). Ankara: Nobel Publishing.

Tondeur, J., Aesaert, K., Pynoo, B., van Braak, J., Fraeyman, N., \& Erstad, O. (2017). Developing a validated instrument to measure preservice teachers' ICT competencies: Meeting the demands of the 21 st century. British Journal of Educational Technology, 48(2), 462-472.Available at: https://doi.org/10.1111/bjet.12380.

Trilling, B., \& Fadel, C. (2009). 21st century skills: Learning for life in ourtimes. Francisco: Jossey-Bass.

Yılmaz, E., \& Alkıs, M. (2019). Development of 21 st century competencies scale: Validity and reliability study. The Journal of International Lingual Social and Educational Sciences, 5(1), 125-154.

Appendix A. Life and career skills scale.

\begin{tabular}{c|c|l}
\hline Dimensions & Item No. & \multicolumn{1}{c}{ Life and Career Skills Scale } \\
\hline Flexibility and & 1 & I can have open and sincere relationships with people. \\
\cline { 2 - 3 } Adaptability & 2 & I have no trouble adapting to different environments. \\
\cline { 2 - 3 } & 3 & I enjoy meeting new people. \\
\cline { 2 - 3 } & 4 & I can develop behaviors suitable for new environment. \\
\hline \multirow{4}{*}{$\begin{array}{c}\text { Entrepreneurship } \\
\text { and }\end{array}$} & 5 & I can manage my time. \\
\cline { 2 - 3 } Self-Management & 6 & I take care to plan my time during the day. \\
\cline { 2 - 3 } & $7^{*}$ & I cannot plan the time well while running my affairs. \\
\cline { 2 - 3 } & 8 & I manage my time and projects effectively. \\
\cline { 2 - 3 } & 9 & I set goals for myself and work in line with my goals. \\
\cline { 2 - 3 } & 10 & When I have trouble doing a job, I look for other ways to engage myself. \\
\hline \multirow{4}{*}{$\begin{array}{c}\text { Productivity and } \\
\text { Skills }\end{array}$} & 11 & I can guide myself while learning new information. \\
\cline { 2 - 3 } & 13 & I present my work within the framework of appropriate etiquette. \\
\cline { 2 - 3 } & 14 & I try to do a job in the best way possible. \\
\cline { 2 - 3 } & 15 & While using my own rights, I observe the rights and responsibilities of others. \\
\hline Leadership and & 16 & I determine the duties and responsibilities of group members in group work. \\
\cline { 2 - 3 } $\begin{array}{c}\text { Responsibility } \\
\text { Skills }\end{array}$ & 17 & I use problem solving skills in the group. \\
\cline { 2 - 3 } & 18 & I use interpersonal skills to guide a group. \\
\cline { 2 - 3 } & 19 & I plan activities for the community of which I am a member to achieve its goals. \\
\cline { 2 - 3 } & 20 & I motivate the group in group work. \\
\hline
\end{tabular}

Note: *Negative Item. 